\title{
Membrane-bound and extracellular $\beta$-lactamase production with developmental regulation in Streptomyces griseus NRRL B-2682
}

\author{
Eleonóra Deák, ${ }^{1}$ István Szabo, ${ }^{1}$ Attila Kálmáczhelyi, ${ }^{1}$ Zsuzsanna Gál, ${ }^{3}$ \\ György Barabás ${ }^{1}$ and András Penyige ${ }^{1,2}$
}

Author for correspondence: Eleonóra Deák. Tel: +3652416 531. Fax: +3652416531.

e-mail: deak@jaguar.dote.hu

Institute of Biology', Research Group for

Microbial Developmental

Genetics, MTA DOTE,

Institute of Biology2 and

Institute of Pharmacology3,

University Medical School

of Debrecen, Debrecen,

Nagyerdei krt. 98, H-4012

Hungary

\begin{abstract}
A new type of $\beta$-lactamase has been isolated and characterized in Streptomyces griseus NRRL B-2682. The enzyme has membrane-bound and extracellular forms. Biochemical characterization of some of the properties of the enzyme showed that it belongs to the class A group of penicillinases. Comparison of the membrane-bound and extracellular forms of the $\beta$ lactamases suggests that they seem to be differently processed forms of the same enzyme. The $\mathbf{N}$-terminal amino acid sequence of the extracellular form of the $\beta$-lactamase showed a high degree of similarity to a D-aminopeptidase of another Streptomyces griseus strain. Secretion of the $\beta$-lactamase was affected by the differentiation state of the strain since in spontaneous non-sporulating mutants only the membrane-bound form was present. In accordance with this when sporulation of the wild-type strain was inhibited it failed to secrete extracellular $\beta$-lactamase. Addition of globomycin to the non-sporulating cells liberated the enzyme from the membrane, indicating that the protein is processed normally by signal peptidase II and a glyceride-thioether group, together with a fatty acid amide-linkage, is responsible for the attachment of the enzyme to the cellular membrane. Under sporulation-repressed conditions addition of peptidoglycan fragments and analogues or inhibition of cell wall biosynthesis by penicillin-G induced $\beta$-lactamase secretion and also restored sporulation both in solid and submerged cultures. These results confirm that $\beta$ lactamase secretion is tightly coupled to the sporulation process in S. griseus.
\end{abstract}

Keywords: Streptomyces griseus, $\beta$-lactamase, sporulation

\section{INTRODUCTION}

Streptomyces spp., representatives of the actinomycetes, are soil bacteria known for their elaborate life cycle. On solid medium spores of Streptomyces griseus germinate to produce a complex network of apically growing hyphae that forms the substrate mycelium (or vegetative mycelium), which later develops into aerial mycelium. This cell type will form the mature spores by a

Abbreviations: AF, A-factor; CA, Casamino acids; GS, glutamine synthetase; $m$-APBA, $m$-aminophenylboronic acid.

The EMBL accession number for the sequence reported in this paper is P81173. synchronous septation process. S. griseus also sporulates abundantly in liquid culture, a rare ability not characteristic of most Streptomyces strains (Kendrick \& Ensign, 1983). Therefore, S. griseus provides an ideal model to study prokaryotic development.

In several Streptomyces strains morphological differentiation, antibiotic production and resistance depend on the presence of small diffusible extracellular autoregulatory factors (Barabás et al., 1994). One of the best known molecules among them is A-factor (AF) $(\gamma-2 S$ isocaprolyl-3S-hydroxymethyl- $\gamma$-butyrolactone) (Horinuchi \& Beppu, 1992; Khoklov et al., 1973; Miyake et al., 1990). S. griseus mutants which do not produce this autoregulator are typically non-sporulating bald mutants. However, both antibiotic production and 
sporulation can be restored by the addition of exogenous AF.

Streptomyces are also known to produce a wide variety of extracellular enzymes, including $\beta$-lactamases (Ogawara, 1981). Certain Streptomyces strains produce $\beta$-lactam compounds, some of which have antibacterial activity and some which act as $\beta$-lactamase inhibitors. One possible explanation for the emergence of $\beta$ lactamases in Gram-positive antibiotic-producing bacteria is that they produce these enzymes to protect themselves from their own secondary metabolites. In producer strains the self resistance genes are part of the antibiotic biosynthetic gene cluster (Pérez-Llarena et al., 1997; J. Martin, personal communication). Approximately half of Streptomyces strains, however, produce $\beta$-lactamases without any apparent relationship to self resistance to $\beta$-lactam compounds (Ogawara, 1996), since most of them are $\beta$-lactam non-producers (Paradkar et al., 1996).

In several Gram-positive bacteria $\beta$-lactamase expression can be induced by the addition of penicillin or peptidoglycan precursors to the medium, as shown in Bacillus licheniformis (Zhu et al., 1992; Joris et al., 1994), but in most Streptomyces strains $\beta$-lactamase production is not inducible (Ogawara, 1981). Rare exceptions are the well known $\beta$-lactamases found in Streptomyces cacaoi (Lenzini et al., 1992; Juana et al., 1992; J. Dusart personal communication). In Escherichia coli induction requires the presence of the AmpR protein and the transport of muropeptides into the cytoplasm (Jacobs et al., 1994, 1997). In Enterobacter cloacae changes in the structure and composition of the cell wall peptidoglycan, caused by the addition of glycine and $\mathrm{D}$-amino acids to cultures, resulted in $\beta$-lactamase induction (Ottolenghi et al., 1993).

In most cases $\beta$-lactamases are extracellular proteins, as they are either excreted into the growth medium in Gram-positive bacteria or they are accumulated in the periplasmic space of Gram-negative bacteria (Nielsen \& Lampen, 1982; Oudega et al., 1993). It is also known, however, that in B. licheniformis and in Bacillus cereus $569 / \mathrm{H}$ the Class A $\beta$-lactamase is present both as a membrane-bound hydrophobic form as well as a soluble exoenzyme (Nielsen \& Lampen, 1982, 1983; Hussain et al., 1987).

Membrane-bound lipoproteins in bacteria are synthesized as prelipoprotein precursors containing N-terminal signal peptides which are subsequently modified by addition of lipids (Wu, 1985; Lampen et al., 1986; Hayashi \& Wu, 1990). The lipophilic modification consists of a diacyl-glycerol group forming a thioether linkage with an $\mathrm{N}$-terminal cysteine residue and a third long-chain fatty acid attached to the same cysteine through an amide linkage (Nielsen \& Lampen, 1983). The N-terminal extension carrying the lipophilic modification is thought to be responsible for membrane anchorage. In later stages of the life cycle these lipoproteins might be excreted into the extracellular space by further processing of the enzyme (Lampen et al.,
1986; Nagarajan, 1993). Globomycin is a cyclic peptide antibiotic which is known to inhibit the processing of bacterial prelipoproteins (Inukai et al., 1978). This inhibition results in secretion of the enzymes into the extracellular space in Gram-positive bacteria (Lampen et al., 1986).

In this publication we show that S. griseus NRRL B2682 produces a membrane-bound and an extracellular form of a $\beta$-lactamase and the release of this enzyme correlates with the differentiation state of the strain. This is further supported by the finding that in a spontaneous, non-sporulating mutant of the wild-type strain, $S$. griseus spo-1, only the membrane-bound form of $\beta$-lactamase could be detected.

\section{METHODS}

Bacterial strains and culture conditions. The wild-type streptomycin producer strain Streptomyces griseus NRRL B2682 was a generous gift from J. C. Ensign, Department of Bacteriology, University of Wisconsin-Madison, USA. Strains spo-1, spo-2 and spo-3, which are spontaneous non-sporulating AF-responsive mutants of $S$. griseus NRRL B-2682, were isolated in our laboratory. Cells were grown in the following media. (i) Defined medium (DM) containing $25 \mathrm{mM}$ Tris/ $\mathrm{HCl}$ (pH 7.2), $50 \mathrm{mM}$ glucose, $5 \mathrm{mM} \mathrm{NH}_{4} \mathrm{Cl}, 0.5 \mathrm{mM}$ $\mathrm{MgCl}_{2}, 10 \mathrm{mM} \mathrm{KH} \mathrm{PO}_{4}, 0.05 \%$ Casamino acids (CA) (Serva) and $0.4 \%$ trace salt (TS) solution (TS is $17 \mathrm{mM} \mathrm{CaCl}_{2}, 5 \mathrm{mM}$ $\mathrm{FeSO}_{4}, 20 \mathrm{mM} \mathrm{MnSO}_{4}, 0.3 \mathrm{mM} \mathrm{ZnSO}$ ) ; in some experiments DM was supplemented with $0.5 \% \mathrm{CA}$ to inhibit the ability of the cells to produce aerial mycelia and spores). (ii) E9 medium containing $10 \mathrm{mM} \mathrm{CaCO}_{3}, 47 \mathrm{mM} \mathrm{NaNO}_{3}, 12 \mathrm{mM} \mathrm{K}_{2} \mathrm{HPO}_{4}$, $6 \mathrm{mM} \mathrm{KCl}, 2 \mathrm{mM} \mathrm{MgSO}_{4}, 50 \mathrm{mM}$ glucose, $0.5 \%$ Bacto peptone and $0.5 \%$ yeast extract $(\mathrm{pH} 7 \cdot 3)$. (iii) Glycerin-casein (GC) medium containing $86 \mathrm{mM} \mathrm{NaCl}, 10 \mathrm{mM} \mathrm{CaCO}_{3}, 4 \mathrm{mM}$ $\mathrm{MgSO}_{4} .7 \mathrm{H}_{2} \mathrm{O}, 57 \mathrm{mM} \mathrm{K}_{2} \mathrm{HPO}_{4}, 3 \mathrm{mM} \mathrm{FeSO}_{4} .7 \mathrm{H}_{2} \mathrm{O}, 35 \mathrm{mM}$ $\mathrm{KOH}$ and $0.05 \% \mathrm{CA}(\mathrm{pH} 7 \cdot 6)$. Liquid media were inoculated with spore suspension and cultures were incubated at $27^{\circ} \mathrm{C}$ on a gyratory shaker at 250 r.p.m. Solid cultures were grown on DM-agar [DM containing $2 \%(\mathrm{w} / \mathrm{v})$ Bacto agar], spore solution was spread on the agar surface and then incubated at $27^{\circ} \mathrm{C}$. Spores of the $s p o-1$ strain were produced by addition of $\mathrm{AF}$ at $3 \times 10^{-7} \mathrm{M}$ to $\mathrm{DM}$-agar and this spore suspension was used to inoculate spo-1 cultures.

Purification of $\beta$-lactamase of Streptomyces griseus NRRL B-2682. The extracellular $\beta$-lactamase present in the supernatant of 48-h-old cultures grown in E9 medium was precipitated with $70 \%(\mathrm{w} / \mathrm{v})\left(\mathrm{NH}_{4}\right)_{2} \mathrm{SO}_{4}$. The precipitate was resuspended in $0.075 \mathrm{M}$ Tris $/ \mathrm{HCl}$ buffer $(\mathrm{pH} 9.4)$ and desalted on a Bio-Gel P6 gel-filtration column $(10 \times 100 \mathrm{~mm}$, Bio-Rad $)$. Active fractions were collected and applied onto an FPLC chromatofocusing column (MonoP HR $5 \times 200 \mathrm{~mm}$, Pharmacia) in the same buffer. The enzyme was eluted with a $\mathrm{pH}$ gradient from $9 \cdot 4$ to 6.0 using tenfold-diluted Polybuffer 96 (Pharmacia) at a flow rate of $1 \mathrm{ml} \mathrm{min} \mathrm{m}^{-1}$. Fractions containing high $\beta$-lactamase activity were collected and concentrated by ultrafiltration (Millipore NMWL 10000 filter). The concentrated samples were loaded onto an FPLC gel-filtration column $(0.8 \times 300 \mathrm{~mm}$, Waters SW 200) using $0.05 \mathrm{M}$ Tris $/ \mathrm{HCl}(\mathrm{pH}$ 7.0) as the eluant buffer at a flow rate $1 \mathrm{ml} \mathrm{min} \mathrm{m}^{-1}$ and active fractions were collected and concentrated as before.

The cellular membrane fractions were prepared as described by Barabás et al. (1988). Mycelium grown in GC medium was harvested by centrifugation at $4000 \mathrm{~g}$ for $25 \mathrm{~min}$ at $4^{\circ} \mathrm{C}$. Cells 
were washed twice with $10 \mathrm{mM}$ Tris/ $\mathrm{HCl}$ buffer $(\mathrm{pH} 7 \cdot 5)$ then resuspended in the same buffer containing $1 \mathrm{mg} \mathrm{lysozyme} \mathrm{\textrm {ml } ^ { - 1 }}$ (Sigma) and $25 \%(\mathrm{w} / \mathrm{v})$ sucrose (Merck). Cells were incubated at $4{ }^{\circ} \mathrm{C}$ overnight and the protoplasts were collected by centrifugation at $2000 \mathrm{~g}$ for $5 \mathrm{~min}$ at $4{ }^{\circ} \mathrm{C}$. The pellet was resuspended in $0.05 \mathrm{M}$ Tris $/ \mathrm{HCl}$ buffer $(\mathrm{pH} 7.2$ ) containing $5 \mathrm{mM} \mathrm{MgCl}_{2}$, washed twice in the same buffer and centrifuged at $1100 \mathrm{~g}$ for $12 \mathrm{~min}$ at $4{ }^{\circ} \mathrm{C}$. Cellular membrane fractions were pelleted by centrifugation at $20000 \mathrm{~g}$ for $30 \mathrm{~min}$ at $4^{\circ} \mathrm{C}$. The membrane-bound form of the enzyme was released from the membrane by limited trypsin digestion at $37^{\circ} \mathrm{C}$ for $30 \mathrm{~min}$ as described by Kharroubi et al. (1989) and purified using the method described above. After gel filtration the active fractions were precipitated with ice-cold $10 \%$ (v/v) TCA containing $125 \mu \mathrm{g}$ deoxycholate $\mathrm{ml}^{-1}$. Precipitated samples were resuspended in sample buffer (Laemmli, 1970), heated at $80^{\circ} \mathrm{C}$ for $5 \mathrm{~min}$ and then loaded onto $13 \%$ SDS-polyacrylamide slab gels. SDS-PAGE was carried out with $35 \mathrm{~mA}$ constant current at $4^{\circ} \mathrm{C}$. The molecular mass of the enzyme was determined by using an SDS-7 (Sigma) molecular mass standard mixture. After electrophoresis gels were equilibrated in $25 \mathrm{mM}$ Tris $/ \mathrm{HCl}$ ( $\mathrm{pH} 9.4$ ) containing $10 \%$ (v/v) methanol and $192 \mathrm{mM}$ glycine (cathode buffer), and subsequently proteins from the gels were electrophoretically blotted to ProBlott $^{\mathrm{TM}}$ (Applied Biosystems) immobilization membrane using a semi-dry system. The following buffers were used for the transfer: (i) Anode buffer I, 0.3 M Tris base containing $10 \%$ methanol ( $\mathrm{pH} \mathrm{10.4);} \mathrm{(ii)} \mathrm{anode} \mathrm{buffer} \mathrm{II,} 25 \mathrm{~mm}$ Tris base containing $10 \%$ methanol ( $\mathrm{pH} 9.4$ ); and (iii) cathode buffer as described above. During the transfer a $2 \mathrm{~mA} \mathrm{~cm}$ constant current was applied for $1 \mathrm{~h}$ and then the blots were stained with Coomassie brilliant blue.

$\mathrm{N}$-terminal sequencing. Sequence analysis based on Edman degradation was performed by a model 910 Knauer Protein Sequencer. The N-terminal sequence of the protein was determined from samples electrotransferred to ProBlott membranes after SDS-PAGE.

Measurement of $\beta$-lactamase activity. (i) $\beta$-Lactamase activity was determined by measuring the hydrolysis of nitrocefin at $37^{\circ} \mathrm{C}$ for $10 \mathrm{~min}$ in $0.05 \mathrm{M} \mathrm{KH}_{2} \mathrm{PO}_{4}$ buffer $(\mathrm{pH} \mathrm{7.0)}$ in $1 \mathrm{ml}$ final volume. One unit was defined as the amount of enzyme that hydrolysed $1 \mu \mathrm{mol}$ nitrocefin under these conditions (O'Callaghan et al., 1972). (ii) Spectrophotometric measurements were carried out in a Shimadzu UV 3000 spectrophotometer equipped with a thermostat cell holder at $37^{\circ} \mathrm{C}$ (Samuni, 1975). For the various substrates the enzyme activity was calculated using the corresponding $\Delta \varepsilon(\lambda)$, where one unit of enzyme activity was defined as the amount of enzyme that hydrolysed $1 \mu \mathrm{mol}$ substrate $\min ^{-1}$ at $37^{\circ} \mathrm{C}, \mathrm{pH} 7 \cdot 0$.

Preparation of crude cellular extract for glutamine synthetase (GS) assays. Crude extracts for GS assays were prepared from mycelia grown in DM medium. Mycelia were centrifuged at $6000 \mathrm{~g}$ at $4{ }^{\circ} \mathrm{C}$ for $20 \mathrm{~min}$ and then cells were disrupted by brief sonication with $30 \mathrm{~s}$ bursts for $2 \mathrm{~min}$ at $4{ }^{\circ} \mathrm{C}$ using a Branson Sonifier model 250. The disrupted cell suspension was centrifuged at $12000 \mathrm{~g}$ for $20 \mathrm{~min}$ at $4^{\circ} \mathrm{C}$ and the resulting supernatant was used as crude cellular extract preparation. The same method was used to prepare cellular membrane fractions to detect membrane-bound penicillinase activity.

GS assay. GS activity was determined by using the $\gamma$ glutamyltransferase assay (Bender et al., 1977). In control experiments reaction mixtures were also prepared without arsenate and ADP to subtract the amount of $\gamma$-glutamyl- hydroxamate produced by enzymes other than GS (less than $3 \%$ of total activity). One unit of enzyme activity was defined as the amount of protein that formed $1 \mathrm{mmol} \gamma$-glutamylhydroxamate $\min ^{-1}$ at $37^{\circ} \mathrm{C}$.

Preparation of cell wall fragments. $S$. griseus cells were disrupted by ultrasonic treatment and cell wall fragments were isolated by the differential centrifugation method (Szabó et al., 1989). The purified cell wall, still containing autolytic enzymes(s), was subjected to exhaustive autolysis by incubating samples in $0 \cdot 1 \mathrm{M}$ ammonium formate buffer ( $\mathrm{pH}$ 9.0) at $5^{\circ} \mathrm{C}$ for $3 \mathrm{~d}$, followed by lyophilization.

\section{RESULTS}

\section{$\mathrm{N}$-terminal sequencing of extracellular $\beta$-lactamase of S. griseus NRRL B-2682}

The extracellular and membrane-bound forms of the $\beta$ lactamase from S. griseus NRRL B-2682 and the membrane-bound form of the enzyme from the spo-1 strain were purified to near homogeneity. During the chromatofocusing step the isoelectric point of both forms of the enzyme was $\mathrm{pH} 7.2$ and their relative molecular masses were found to be $31000 \mathrm{Da}$ on SDSPAGE, according to their relative mobility (Fig. 1). The $\mathrm{N}$-terminal sequence of the extracellular enzyme determined after electroblotting was AAAPDIPIANVNA. Comparison of the first 11 aa of this sequence with sequences present in the EBI database showed $81.8 \%$ similarity to the $\mathrm{N}$-terminal sequence, APDIPLANVKA,

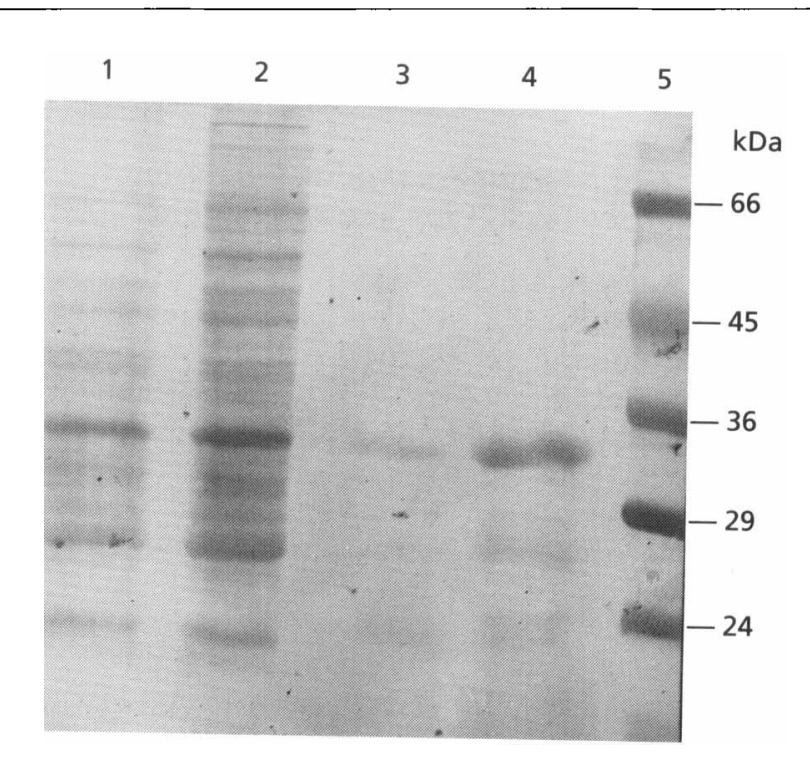

Fig. 1. Coomassie-brilliant-blue-stained electroblot analysis of the purified extracellular and membrane-bound $\beta$-lactamase of S. griseus NRRL B-2682. Proteins were separated by SDS-PAGE $(13 \%)$ and then electrophoretically transferred from the gel to ProBlott membrane. Lanes represent samples from concomitant purification steps: 1,2 , active fractions after chromatofocusing of the precipitated extracellular proteins; 3, purified membrane-bound enzyme after gel filtration; 4, purified extracellular enzyme after gel filtration; 5, molecular mass markers. The relative molecular mass of the membrane-bound and the extracellular $\beta$-lactamase was found to be $31000 \mathrm{Da}$. 


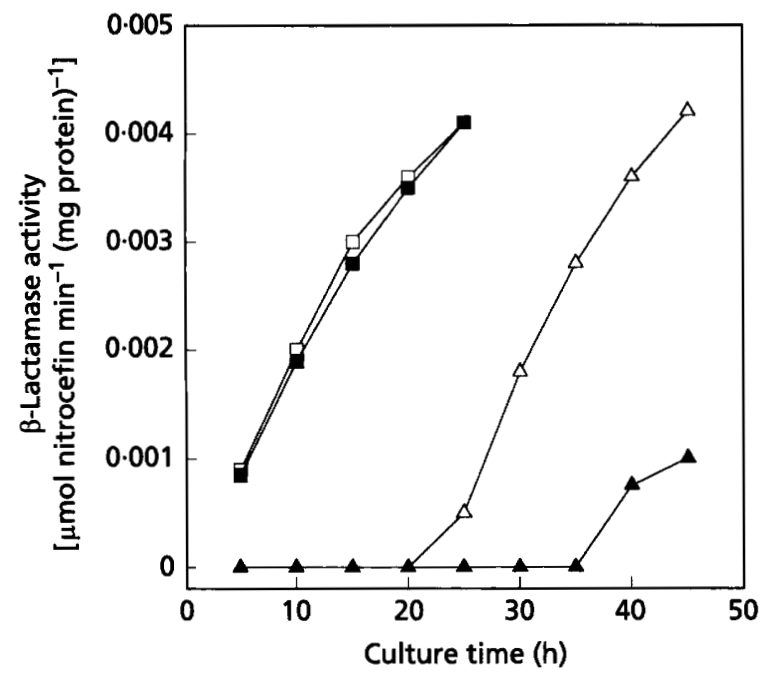

Fig. 2. Comparison of the time course of $\beta$-lactamase production in S. griseus NRRL B-2682 and in non-sporulating mutant strain spo-1. Cells were grown in DM liquid medium at $27^{\circ} \mathrm{C}$ and $\beta$-lactamase activity was measured at the indicated time in the isolated cellular membrane $(\square, \square)$ and in the supernatant $(\triangle, \Delta)$ of the wild-type and the spo-1 mutant strain, respectively. Values are means of three independent measurements.

of the D-aminopeptidase enzyme of another S. griseus strain (Maras et al., 1996). Our enzyme did not show aminopeptidase activity. Previously, another $\beta$-lactamase was also found to show similarity to D-aminopeptidases (Asano et al., 1992).

\section{Time course of $\beta$-lactamase production during the life} cycle of S. griseus wild-type and spo mutants

To study $\beta$-lactamase production in the wild-type $S$. griseus NRRL B-2682 and in its spontaneous nonsporulating mutant, spo-1, the localization of $\beta$-lactamase and the time course of its expression were determined first. In wild-type cells grown in liquid DM medium, $\beta$-lactamase activity was initially detected in the cellular membrane of 5 -h-old cells, while the extracellular form of the enzyme appeared much later at $24 \mathrm{~h}$. In contrast to this, in the spo-1 strain only the membrane-bound form of the $\beta$-lactamase was present; the time course of its activity profile was similar to the wild-type strain (Fig. 2). The appearance of a low level of extracellular $\beta$-lactamase activity in 40-h-old spo-1 cultures was very likely due to lysis of a certain proportion of the cells. This result was confirmed in two additional non-sporulating mutants, spo-2 and spo-3. Neither of these two strains secreted extracellular $\beta$ lactamase activity; only the membrane-bound form of the enzyme was detectable during their whole life cycle (data not shown). As shown in Table 1, addition of $80 \mu \mathrm{g} \mathrm{AF} \mathrm{ml}^{-1}$ at $6 \mathrm{~h}$ after inoculation to the spo-1 strain grown in liquid DM medium induced the secretion of the extracellular $\beta$-lactamase with a time course profile
Table 1. Effect of AF on $\beta$-lactamase secretion of the $S$. griseus spo-1 mutant

Cells were grown in DM liquid medium at $27^{\circ} \mathrm{C}$ and sampled at 26,32 and $48 \mathrm{~h}$ after inoculation. AF was added at $80 \mu \mathrm{g}$ $\mathrm{ml}^{-1}$ to 6 -h-old cells and $\beta$-lactamase activity was measured in the supernatant of the culture after mycelium was harvested by centrifugation at $4000 \mathrm{~g}$ for $30 \mathrm{~min}$ at $4^{\circ} \mathrm{C}$.

\begin{tabular}{|lccc|}
\hline Strain & \multicolumn{3}{c|}{$\begin{array}{c}\boldsymbol{\beta} \text {-Lactamase specific } \\
\text { activity (units) }\end{array}$} \\
\cline { 2 - 4 } & $26 \mathrm{~h}$ & $32 \mathrm{~h}$ & $48 \mathrm{~h}$ \\
\hline S. griseus NRRL B-2682 & $1 \times 10^{-3}$ & $3 \times 10^{-3}$ & $5 \times 10^{-3}$ \\
S. griseus spo-1 & 0 & 0 & $1.2 \times 10^{-4}$ \\
S. griseus spo-1 + AF & 0 & $1.3 \times 10^{-3}$ & $2.7 \times 10^{-3}$ \\
\hline
\end{tabular}

similar to that of the wild-type strain and sporulation of the mutant was also restored as expected.

Previously we have reported that low concentrations $(15 \mu \mathrm{M})$ of $m$-aminophenylboronic acid ( $m$-APBA) (Penyige et al., 1996) or $0.5 \%$ casein hydrolysate (de-losReyes-Gavilán et al., 1991) inhibited sporulation of $S$. griseus NRRL B-2682 cells in liquid medium. When sporulation was suppressed by addition of these agents extracellular $\beta$-lactamase activity was not detected in the supernatant of wild-type cultures (data not shown).

\section{Characterization of the membrane-bound and extracellular forms of $\beta$-lactamase in $S$. griseus wild- type and spo-1 mutant}

To characterize the enzyme we isolated both forms of the $\beta$-lactamase from wild-type cultures and the membrane-bound form from the spo-1 mutant strain. Substrate specificity of the purified enzymes was determined against various $\beta$-lactam compounds, such as benzylpenicillin and ampicillin, as well as first, second and third generation cephalosporins as described by Bush (1989). Among the substrates tested, benzylpenicillin was the best substrate for the various forms of the $\beta$-lactamase. Ampicillin was hydrolysed at a similar rate in all cases. The first generation cephalosporins, cefamandole and cephaloridine, were poor substrates for all forms, while other cephalosporins, like cefuroxime, cefotaxime and ceftazidine were not hydrolysed at all. According to these results the $\beta$-lactamases we have isolated are penicillinases rather than cephalosporinases.

The effect of various kinds of inhibitors on the activity of purified $\beta$-lactamases was also determined using nitrocefin as substrate (Bush, 1989). Among the compounds tested $m$-APBA at a concentration above $1 \mathrm{mM}$ showed the strongest inhibitory effect on the enzyme activity and $1 \mathrm{mM} p$-chloromercuribenzoate was also significantly inhibitory. The inhibitory effect of $p$ chloromercuribenzoate could be reversed by addition of equimolar amounts of cysteine (data not shown). 


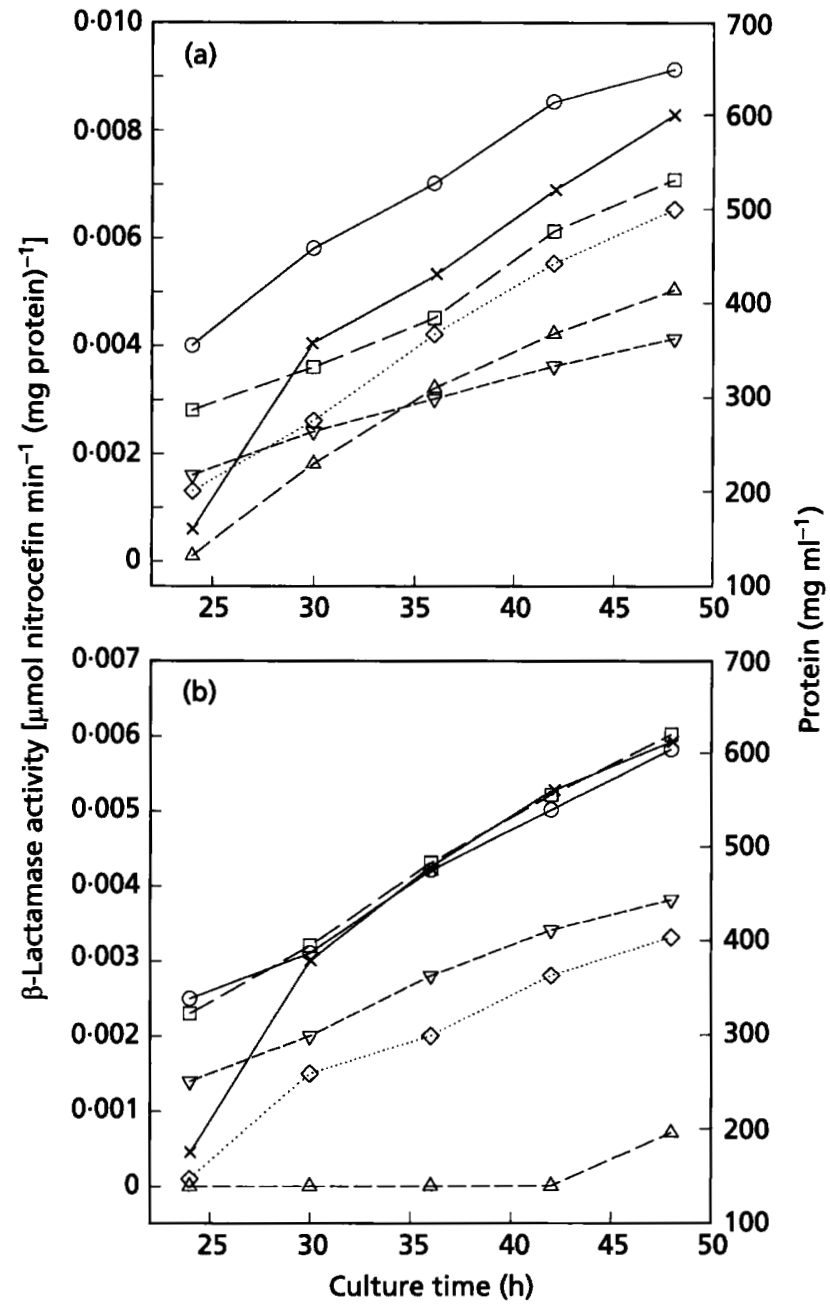

Fig. 3. Effect of globomycin on growth, $\beta$-lactamase production and secretion of S. griseus NRRL B-2682 (a) and non-sporulating mutant strain spo-1 (b) grown in DM liquid medium. Globomycin was added at $50 \mu \mathrm{g} \mathrm{ml}^{-1}$ to 5 -h-old cells. $\beta$ Lactamase activity was measured in the membrane fraction in the absence $(\square)$ and presence $(\nabla)$ of globomycin and in the extracellular space in the absence $(\Delta)$ and presence $(\diamond)$ of globomycin. Total penicillinase production $(x)$ was determined; this was not affected by globomycin (data not shown). The amount of protein (O) in the sample was determined by the Lowry method.

Inhibition by $m$-APBA may suggest the presence of active site serine residue(s) in the enzyme, while the inhibitory effect of $p$-chloromercuribenzoate predicts the presence of a catalytically important cysteine residue in these $\beta$-lactamases (Bush, 1989). $\mathrm{NaCl}(100 \mathrm{mM})$ and (1 mM EDTA) did not affect $\beta$-lactamase activity.

The $K_{\mathrm{i}}$ values of some of the well-known $\beta$-lactamase inhibitors were also determined (Bush, 1989). Both the extracellular and membrane-bound forms of the $\beta$ lactamase of $S$. griseus NRRL B-2682 and the membrane-bound enzyme of the spo-1 mutant were susceptible to inhibition by clavulanic acid and sulbactam, while cloxacillin had a weaker effect (data not

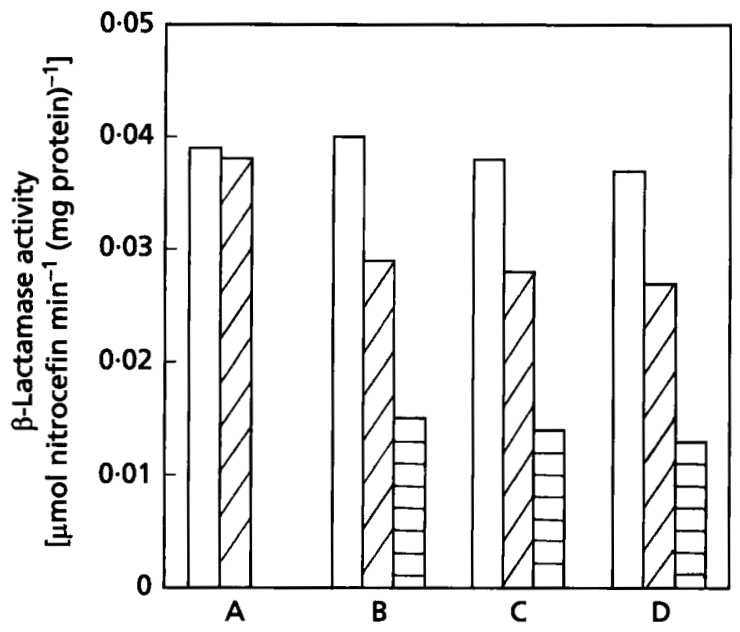

Fig. 4. Comparison of $\beta$-lactamase activity present in different fractions of S. griseus NRRL B-2682 grown at $27^{\circ} \mathrm{C}$ in DM liquid medium supplemented with $0.5 \%$ CA. Enzyme activities were determined at $36 \mathrm{~h}$ after inoculation. Total $\beta$-lactamase activity ( $\square)$, membrane-bound activity ( $\square$ ) and extracellular $\beta$ lactamase activity (目) of $S$. griseus in control cultures (A), in cultures supplemented with $\mathrm{AC}_{2}$-L-Lys-D-Ala-D-Ala (B), with purified autolysin-digested cell wall fragments (C) and with penicillin-G (D). Values represent means of three independent measurements.

shown). These results show good correlation with our substrate specificity studies since it is known that clavulanic acid and sulbactam are irreversible suicidal $-\beta$ lactamase inhibitors and penicillinases have stronger affinity for clavulanic acid than cephalosporinases, whereas cloxacillin has been recognized to be a good inhibitor for cephalosporinases (Bush, 1989). Since all of the investigated characteristics of the differently localized $\beta$-lactamases were the same, we concluded that these are differently processed forms of the same protein.

\section{Effect of globomycin on $\beta$-lactamase production of $S$. griseus wild-type and spo-1 mutant}

To verify the type of membrane anchorage of the $\beta$ lactamase, the effect of globomycin on $\beta$-lactamase secretion was examined in the wild-type strain and in the spo-1 mutant. Globomycin $\left(50 \mu \mathrm{g} \mathrm{ml}^{-1}\right)$ added to the $\mathrm{DM}$ liquid medium at $5 \mathrm{~h}$ after inoculation did not inhibit the growth of these strains. However, in both strains it enhanced the release of the soluble form of the enzyme compared to that of the non-treated control cultures while simultaneously reducing the amount of the membrane-bound form. The total amount of enzyme activity was not effected by globomycin (Fig. 3). In the mutant strain the time course of globomycin-induced $\beta$ lactamase secretion was very similar to that of the wildtype (Fig. 3b). The increase in $\beta$-lactamase secretion after the addition of globomycin suggests that the membrane-bound form of the enzyme possesses an $\mathrm{N}$ terminal Cys-glyceride-thioether modification in $S$. griseus NRRL B-2682 (Nagarajan, 1993). 


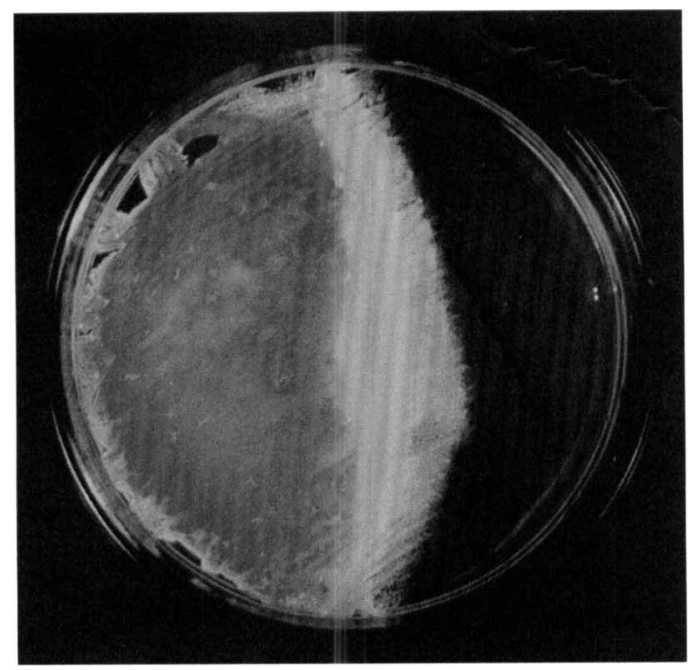

Fig. 5. Effect of penicillin-G on growth and differentiation of $S$. griseus NRRL B-2682. Cells were grown at $27^{\circ} \mathrm{C}$ on DM-agar containing $0.5 \%$ CA. In the gradient plate method the lower DM-agar layer was supplemented with $100 \mu \mathrm{g}$ penicillin-G ml $\mathrm{m}^{-1}$. The effect of penicillin- $G$ was analysed at $48 \mathrm{~h}$ after inoculation. The white area in the centre of the plate indicates aerial mycelium and spore production.

\section{Effect of purified autolysin-digested cell wall fragments, $A C_{2}-L-L y s-D-A l a-D-A l a$ and penicillin-G on $\beta$-lactamase production in S. griseus NRRL B-2682}

It has been reported that $\beta$-lactamase induction is regulated by the intracellular level of muropeptides in $E$. coli (Jacobs et al., 1994, 1997). To determine the possible involvement of peptidoglycan precursors in $\beta$-lactamase production or secretion in $S$. griseus NRRL B-2682, we examined the effect of purified autolysin-digested cell wall fragments and the cell wall analogue tripeptide $A c_{2}-$ L-Lys-D-Ala-D-Ala on $\beta$-lactamase production. In parallel experiments we also tested the effect of penicillin-G at subinhibitory concentration on- $\beta$-lactamase production and secretion, since $\beta$-lactams interact with bacterial penicillin-binding proteins and thus may increase the release of murein-derived fragments. These agents were added to 5-h-old S. griseus NRRL B-2682 cells grown in DM liquid medium supplemented with $0.5 \% \mathrm{CA}$ to inhibit sporulation and suppress extracellular $\beta$-lactamase production. $\beta$-Lactamase activity was measured in the culture supernatant and crude extracts of the cells, and total enzyme activity was also determined. As shown in Fig. 4, addition of purified digested cell wall fragments at $0.2 \mathrm{mg} \mathrm{ml}^{-1}, \mathrm{Ac}_{2}$-L-Lys-DAla-D-Ala at $0.5 \mathrm{mM}$ and penicillin-G at $35 \mathrm{nM}$ increased the level of secretion of $\beta$-lactamase into the extracellular fluid compared to the control cultures. At the same time these compounds reduced the amount of the membrane-bound form of the enzyme. The total $\beta$ lactamase activity remained the same in all cases.

To ensure that the increase in the amount of extracellular $\beta$-lactamase was not due to cell lysis, we also measured GS activity, which is known to be a strictly intracellular enzyme in S. griseus NRRL B-2682 (Penyige et al., 1994), in the extracellular fluid. Our results showed that the presence of extracellular $\beta$-lactamase activity was not due to cell lysis, since GS was not detectable in the extracellular space; it was only detectable in crude cellular extracts.

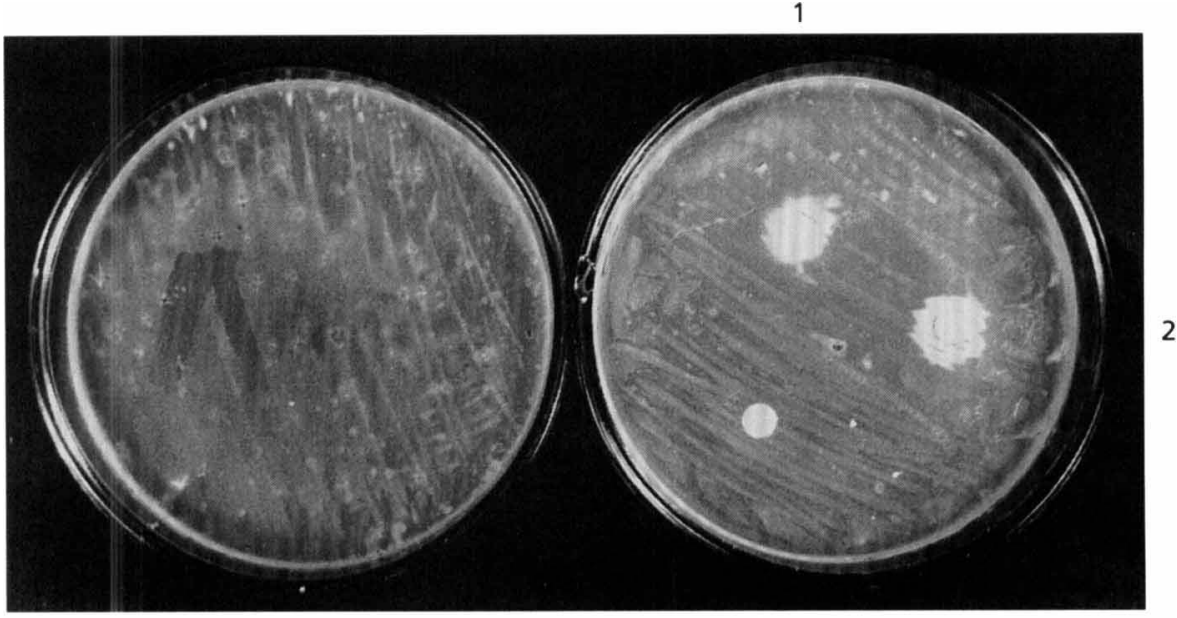

3

Fig. 6. Agar diffusion test showing the age-dependent effect of penicillin-G on the differentiation of $S$. griseus NRRL B-2682. Cells were grown at $27^{\circ} \mathrm{C}$ on DM-agar containing $0.5 \%$ CA. The control plate is shown on the left, penicillin-Gsupplemented samples on the right. Paper discs containing $27(1)$ and $34 \mathrm{nmol}(2,3)$ penicillin-G were placed on the agar surface $5(1,2)$ and $24 \mathrm{~h}(3)$ after inoculation. The photograph was taken $48 \mathrm{~h}$ after inoculation. The white area around the discs shows aerial mycelium and spore production. 

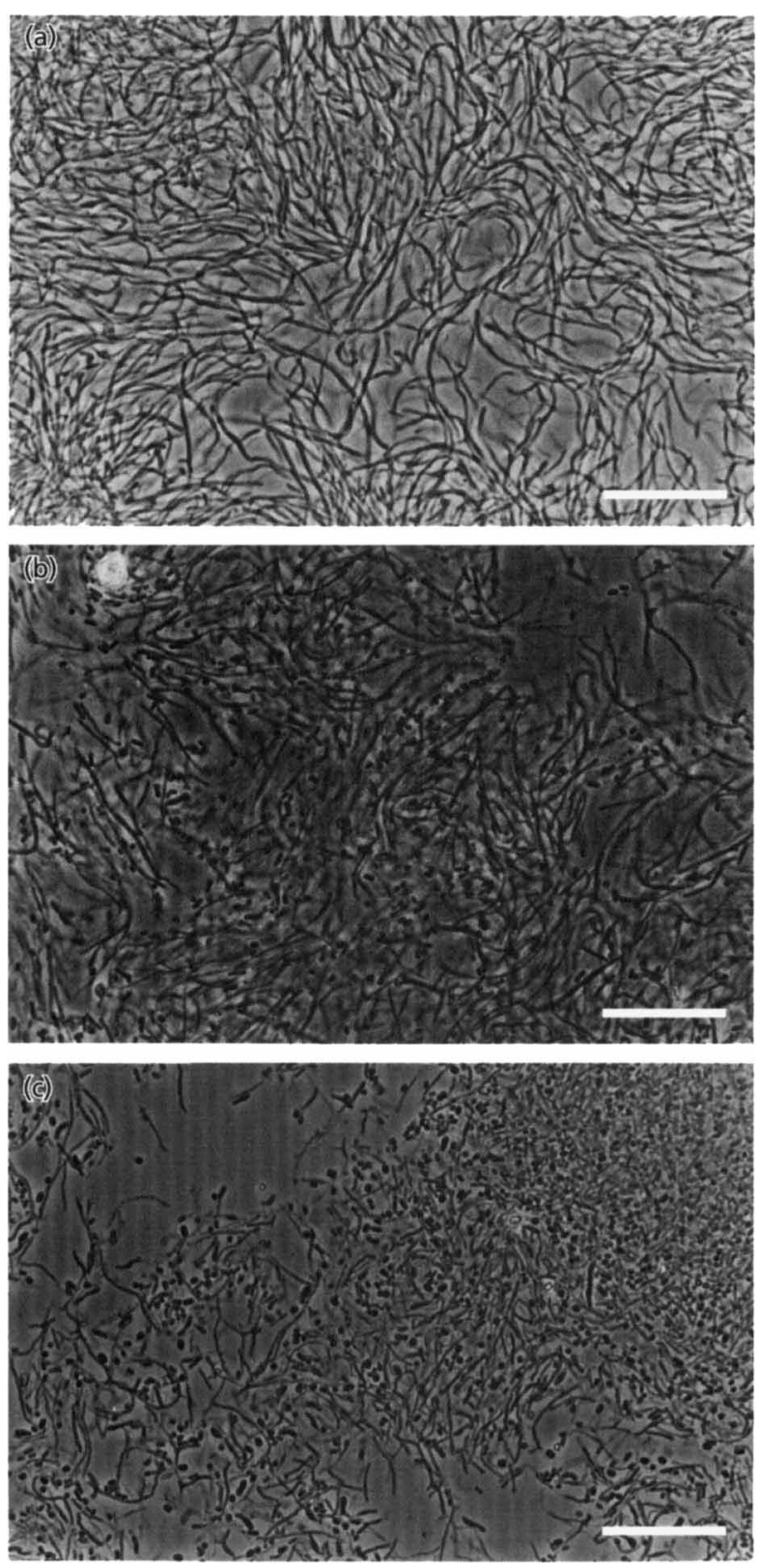

Fig. 7. Phase-contrast micrographs of submerged cultures showing the effect of peptidoglycan fragments, analogues and penicillin-G on the differentiation of $S$. griseus NRRL B-2682 cells grown at $27^{\circ} \mathrm{C}$ in DM medium supplemented with $0.5 \%$ CA. (a) Control culture in which the cells were impaired in sporulation and altered cell morphology in the presence of penicillin-G ( $33 \mathrm{nmol} \mathrm{ml} \mathrm{m}^{-1}$ ) added to 5-h-old cells (b) and purified cell wall fragments $\left(0.1 \mathrm{mg} \mathrm{ml}^{-1}\right)$ added to 5 -h-old cells (c). The photographs were taken at $60(a, b)$ and $72 \mathrm{~h}(\mathrm{c})$ after inoculation. Bars, $25 \mu \mathrm{m}$.

Effect of penicillin-G, purified autolysin-digested cell wall fragments, $A C_{2}-L-L y s-D-A l a-D-A l a$ and adjuvant peptide ( $\mathrm{N}$-AcMur-L-Ala-D-isoglutamine) on the growth and differentiation of S. griseus

While studying the effect of penicillin-G on $\beta$-lactamase production of CA-suppressed S. griseus cultures, to our surprise we found that penicillin-G in concentrations lower than its MIC $\left(90 \mu \mathrm{g} \mathrm{ml}^{-1}\right)$ affected the differentiation of the strain. To visualize this effect a simple gradient plate technique was used (Eisenstadt et al., 1994). A slanted layer of DM-agar containing $0.5 \%$ CA supplemented with $100 \mu \mathrm{g}$ penicillin-G ml $\mathrm{m}^{-1}$ was covered with DM medium containing $0.5 \% \mathrm{CA}$ without the antibiotic. The effect of the resulting antibiotic gradient on the morphological differentiation of the strain is shown in Fig. 5. Penicillin-G at high concentration strongly inhibited growth and spore germination (right), while at a subinhibitory concentration it restored aerial mycelium and spore production (in a narrow intensely white band, centre) and had no effect at low concentration (left) in CA-suppressed cultures.

It has been suggested that $S$. griseus becomes committed to sporulation at $16-18 \mathrm{~h}$ after inoculation in $\mathrm{DM}$ medium (Ensign, 1988). The effect of penicillin-G as a function of culture age was also examined using an agar diffusion test. Paper discs containing 27 or $34 \mathrm{nmol}$ penicillin-G were placed on the DM-agar plate containing $0.5 \% \mathrm{CA}$ at 5 and $24 \mathrm{~h}$ after inoculation. The morphological changes (sporulation) caused by penicillin-G were only seen when the antibiotic was applied to the culture at $5 \mathrm{~h}$ after inoculation; penicillin-G added to 24-h-old cells was ineffective (Fig. 6). Sporulation was confirmed by phase-contrast microscopy. The same result was obtained with ampicillin and cephaloridine (data not shown). Since $S$. griseus is able to sporulate in liquid cultures we tested the effect of penicillin-G in submerged cultures using DM medium containing $0.5 \% \mathrm{CA}$. At a subinhibitory concentration $(33 \mathrm{nmol})$ penicillin-G counteracted the inhibitory effect of CA on the normal differentiation and restored spore formation (Fig. 7b). However, sporulation was delayed by $24 \mathrm{~h}$ compared to the normal life cycle. The same effect was observed after addition of $0 \cdot 1 \mathrm{mg}$ digested cell wall fragments $\mathrm{ml}^{-1}$ (Fig. 7c) to CA-suppressed S. griseus cultures. In this experiment sporulation was delayed by $12 \mathrm{~h}$ only. Phase-contrast microscopy was also used to confirm spore formation in these cases (Fig. 7). Addition of $0 \cdot 2 \mu \mathrm{mol} \mathrm{Ac} \mathrm{Ac}_{2}$-L-Lys-D-Ala-D-Ala, $0 \cdot 25 \mu \mathrm{mol}$ adjuvant peptide or digested cell wall fragments to cells grown on DM-agar under sporulation-repressed conditions also resulted in aerial mycelium and mature spore production when these agents were added to 5-h-old cells (data not shown). In identical control experiments we have used amino acids and peptides that are not components of peptidoglycan and in those cases no effect on the differentiation process of CA-suppressed S. griseus cells was observed (data not shown).

\section{DISCUSSION}

In studying- $\beta$-lactamase production in $S$. griseus NRRL B-2682 we have found that the wild-type strain produced a membrane-bound and an extracellular form of the same $\beta$-lactamase, while its non-sporulating spo-1 mutant produced only the membrane-bound enzyme. Examination of the time course of $\beta$-lactamase production in cultures of the wild-type and the spo-1 mutant showed that $\beta$-lactamase activity was first 
detectable in the membrane of 5 -h-old cells, just after the appearance of the germ tubes. Extracellular enzyme activity was first detectable in the late exponential phase of growth of the wild-type strain. It was low at first [0.0006 units (mg protein $)^{-1}$, then increased about eightfold during the late exponential and early stationery phases. By contrast, the $s p o-1$ strain did not produce any extracellular $\beta$-lactamase and only membrane-bound activity was detectable during the whole life cycle. Addition of the autoregulator $\mathrm{AF}$ at a concentration of $80 \mu \mathrm{g} \mathrm{m}^{-1}$ to 5 -h-old spo-1 mutant cells grown in DM liquid medium restored sporulation and resulted in the secretion of the $\beta$-lactamase into the extracellular fluid. These results suggest that the secretion-of- $\beta$-lactamase into the extracellular space is tightly coupled to the differentiation process. This observation was further supported by the fact that in all cases when cells of the wild-type strain were impaired in their ability to develop mature spores (by the addition of $0.5 \% \mathrm{CA}$ or $15 \mu \mathrm{M} \mathrm{m}$ APBA to submerged cultures), the secretion of $\beta$ lactamase into the medium was also inhibited.

Since all of the $\beta$-lactamases isolated so far from Streptomyces spp. have been reported to be constitutively synthesized extracellular enzymes, to our knowledge this is the first example of a membranebound $\beta$-lactamase isolated from Streptomyces.

In our experiments, globomycin, which specifically inhibits the bacterial signal peptidase II responsible for the processing of the membrane-bound lipoproteins (Hayashi \& Wu, 1990), prevented the accumulation of the membrane-bound $\beta$-lactamase enzyme both in the wild-type and mutant strain. A possible explanation of this phenomenon is that in the absence of processing of the $\mathrm{N}$-terminal signal peptide, due to the inhibitory effect of globomycin, the N-terminal Cys is not generated. Since this residue is the site for subsequent lipid modifications, in the absence of the available acceptor this lipid anchor is missing and as a result the unmodified $\beta$-lactamase is released into the extracellular space. Our results indicate that in $S$. griseus NRRL B-2682 $\beta$ lactamase is synthesized first as a prelipoprotein and, after proper processing, the enzyme has a post-translationally modified membrane-bound form which is later released to the extracellular space.

In E. coli it was found that recycling of peptidoglycan fragments generated by cell wall turnover regulated $\beta$ lactamase gene expression (Jacobs et al., 1994, 1997). In studying a possible connection between cell wall biosynthesis and $\beta$-lactamase production we have analysed the effect of purified autolysin-digested cell wall fragments, the cell wall analogue $\mathrm{Ac}_{2}$-L-Lys-D-Ala-D-Ala and penicillin-G on $\beta$-lactamase production in S. griseus. Our results indicated that in wild-type cultures the secretion of $\beta$-lactamase into the extracellular space was enhanced by addition of these agents to cells grown under sporulation-repressed conditions. However, no induction of the $\beta$-lactamase gene was observed, indicating that the enzyme is constitutive in S. griseus NRRL B-2682. Thus, it can be concluded that increased levels of cell wall fragments/precursors are important factors which can affect the release of the $\beta$-lactamase from the cellular membrane.

While studying the effect of cell wall fragments, precursors and $\beta$-lactam antibiotics on $\beta$-lactamase secretion we noticed that these agents produced significant morphological changes in sporulation-repressed cultures of wild-type $S$. griseus. They overcame the inhibitory effect of CA and restored the ability of these cells to produce spores on solid medium and in liquid cultures. It is possible that increased amounts of cell wall precursors present both in the extra- and intracellular spaces influence the differentiation process of $S$. griseus, possibly by serving as a signal for initiation of the sporulation process. The restoration of the normal differentiation process was invariably coupled to the secretion of the extracellular $\beta$-lactamase enzyme.

We propose that in $S$. griseus there might be an indirect link between $\beta$-lactamase secretion and the turnover of cell wall fragments. Cell wall metabolism may provide feed-back signals to regulate differentiation and $\beta$ lactamase secretion could be a consequence of the normal sporulation process in this bacterium.

\section{ACKNOWLEDGEMENTS}

Globomycin was a generous gift from Masatoshi Inukai (Sankyo Company, Tokyo, Japan). We thank Szilágyi Istvánné for her skilful technical assistance and Miklósné Durkó Ábgnes for the photos. We are also grateful to Boross Péter and Tõzsér József (Institute of Biochemistry and Molecular Cell Biology, University Medical School of Debrecen, Hungary) for N-terminal sequencing of the enzyme. This work was supported by grant OTKA T 020281 from the Hungarian Government.

\section{REFERENCES}

Asano, Y., Kato, Y., Yamada, A. \& Kondo, K. (1992). Structural similarity of $\mathrm{D}$-aminopeptidase to carboxypeptidase DD and $\beta$ lactamases. Biochemistry 31, 2316-2328.

Barabás, Gy., Penyige, A., Hirano, T., (1994). Hormone-like factors influencing differentiation of Streptomyces cultures. FEMS Microbiol Rev 14, 75-82.

Barabás, J., Barabás, Gy., Szabó, I., Veerhuis, M. \& Harder, W. (1988). Penicillin-binding proteins of protoplast and sporoplast membranes of Streptomyces griseus strains. Arch Microbiol 150, 105-108.

Bender, R. A., Janssen, K. A., Resnick, A. D. M., Blumenberg, F. F. \& Magasanik, B. (1977). Biochemical parameters of glutamine synthetase from Klebsiella aerogenes. J Bacteriol 129, 1001-1009.

Bush, K. (1989). Characterization of $\beta$-lactamases. Antimicrob Agents Chemother 33, 259-263.

Eisenstadt, E., Carlton, B. C. \& Brown, B. J. (1994). Molecular genetics: gene mutation. In Methods for General and Molecular Bacteriology, pp. 297-317. Edited by P. Gerhardt, R. G. E. Murray, W. A. Wood \& N. R. Krieg. Washington, DC: American Society for Microbiology.

Ensign, J. C. (1988). Physiological regulation of sporulation of Streptomyces griseus. In Biology of Actinomycetes '88, pp. 
309-315. Edited by Y. Okami, T. Beppu \& H. Ogawara. Tokyo: Japan Scientific Press.

Hayashi, S. \& Wu, H. C. (1990). Lipoproteins in bacteria. J Bioenerg Biomembr 22, 451-471.

Horinouchi, S. \& Beppu, T. (1992). Autoregulatory factors and communication in Actinomycetes. Annu Rev Microbiol 46, 377-398.

Hussain, M., Pastor, F. I. J. \& Lampen, J. O. (1987). Cloning and sequencing of the bla $z$ gene encoding a $\beta$-lactamase III, a lipoprotein of Bacillus cereus 569/H. J Bacteriol 169, 579-586.

Inukai, M., Takeuchi, M., Shimizu, K. \& Arai, M. (1978). Mechanism of action of globomycin. J Antibiot 31, 1203-1205.

Jacobs, C., Huang, L.-J., Bartowsky, E., Normark, S. \& Park, J. T. (1994). Bacterial cell wall recycling provides cytosolic muropeptides as effectors for $\beta$-lactamase induction. EMBO $J 13$, 4684-4694.

Jacobs, C., Frere, J. M. \& Normark, S. (1997). Cytosolic intermediates for cell wall biosynthesis and degradation control inducible $\beta$-lactam resistance in Gram-negative bacteria. Cell 88, 823-832.

Joris, B., Hardt, K. \& Ghuysen, J. M. (1994). Induction of $\beta$ lactamase and low affinity penicillin-binding protein 2 synthesis in Gram-positive bacteria. New Compr Biochem 27, 505-515.

Juana, M., Forsman, M., Lenzini, M. V., Brans, A. \& Dusart, J. (1992). Two different $\beta$-lactamase genes are present in Streptomyces cacaoi. FEMS Microbiol Lett 99, 101-106.

Kendrick, K. E. \& Ensign, J. C. (1983). Sporulation of Streptomyces griseus in submerged culture. J Bacteriol 155, 357-366.

Kharroubi, E. A., Piras, G., Jacques, P., Szabb, I., Van Beeumen, J., Coyette, J. \& Ghuysen, J. M. (1989). Active-site membrane topology of the DD-peptidase/penicillin-binding protein no. 6 of Enterococcus birae (Streptococcus faecium) ATCC 9790. Biochem J 262, 457-462.

Khokhlov, A. S., Anisova, L. N., Tovarova, I. I., Kleine, E. M., Krassilnkova, O. S., Kornitskaya, E. Y. \& Pilner, S. A. (1973). Effect of A-factor on growth of asporogeneous mutant of Streptomyces griseus not producing this factor. Z Allg Mikrobiol 13, 647-655.

Laemmli, U. K. (1970). Cleavage of structural proteins during the assembly of the head of bacteriophage T4. Nature 227, 680-685.

Lampen, J. O., Pastor, F. I. J. \& Hussain, M. (1986). Processing of secreted proteins and the signal peptidases of bacilli. In Microbiology-1985, pp. 279-282. Edited by L. Leive. Washington, DC: American Society for Microbiology.

Lenzini, M. V., Juana, M., Fraipont, C., Joris, B., Matagne, A. \& Dusart, J. (1992). Induction of a Streptomyces cacaoi $\beta$-lactamase gene cloned in S. lividans. Mol Gen Genet 235, 41-48.

Maras, B., Greenblatt, H. M., Shoham, G., Spungin-Bialik, A., Blumberg, S. \& Barra, D. (1996). Aminopeptidase from Streptomyces griseus: primary structure and comparison with other zinc-containing aminopeptidases. Eur J Biochem 236, 843-846.

Miyake, K., Kuzuyama, T., Horinouchi, S. \& Beppu, T. (1990). The A-factor binding protein of Streptomyces griseus negatively controls streptomycin production and sporulation. $J$ Bacteriol $175,133-140$.

Nagarajan, V. (1993). Transcription and translation machinery: protein secretion. In Bacillus subtilis and Other Gram-positive Bacteria: Biochemistry, Physiology, and Molecular Genetics, pp. 713-729. Edited by A. L. Sonenshein, J. A. Hoch \& R. Losick. Washington, DC: American Society for Microbiology.

Nielsen, J. B. K. \& Lampen, J. O. (1982). Membrane-bound penicillinases in Gram-positive bacteria. J Biol Chem 257, 4490-4495.
Nielsen, J. B. K. \& Lampen, J. O. (1983). $\beta$-Lactamase III of Bacillus cereus 569: membrane lipoprotein and secreted protein. Biochemistry 22, 4652-4656.

O'Callaghan, C. H., Morris, A., Kirby, S. \& Shingler, A. H. (1972). Novel method for detection of $\beta$-lactamase by using a chromogenic cephalosporin substrate. Antimicrob Agents Chemother 1, 283-288.

Ogawara, H. (1981). Antibiotic resistance in pathogenic and producing bacteria, with special reference to $\beta$-lactam antibiotics. Microbiol Rev 45, 591-619.

Ogawara, H. (1996). Structure and evolution of $\beta$-lactamase genes from Streptomyces. Actinomycetes 10, 104-111.

Ottolenghi, A. C., Caparrós, M. \& de Pedro, M. A. (1993). Peptidoglycan tripeptide content and cross-linking are altered in Enterobacter cloacae induced to produce AmpC $\beta$-lactamase by glycine and D-amino acids. J Bacteriol 175, 1537-1542.

Oudega, B., Clark, D., Stegehuis, F., Majoor, M. J. \& Luirink, J. (1993). A lipoprotein signal peptide plus a cysteine residue at the amino terminal end of the periplasmic protein $\beta$-lactamase is sufficient for its lipid modification, processing and membrane localization in Escherichia coli. FEMS Microbiol Lett 108, 353-360.

Paradkar, A. S., Kwamena, A. A., Wong, A. \& Jensen, S. E. (1996). Molecular analysis of a $\beta$-lactam resistance gene encoded within the cephamycin gene cluster of Streptomyces clavuligerus. $J$ Bacteriol 178, 6266-6274.

Penyige, A., Kálmánczhelyi, A., Sipos, A., Ensign, J. C. \& Barabás, Gy. (1994). Modification of glutamine synthetase in Streptomyces griseus by ADP-ribosylation and adenylylation. Biochem Biophys Res Commun 204, 598-605.

Penyige, A., Deák, E., Kálmánczhelyi, A. \& Barabás, Gy. (1996). Evidence of a role for $\mathrm{NAD}^{+}$-glycohydrolase and ADP-ribosyltransferase in growth and differentiation of Streptomyces griseus NRRL B-2682 : inhibition by $m$-aminophenylboronic acid. Microbiology 142, 1937-1944.

Pérez-Llarena, J. F., Liras, P., Rodríguez-García, A. \& Martin, J. F. (1997). A regulatory gene $(c c r)$ required for cephamycin and clavulanic acid production in Streptomyces clavuligerus: amplification results in overproduction of both $\beta$-lactam compounds. $J$ Bacteriol 179, 2053-2059.

de-los-Reyes-Gavilán, C., Cal, S., Barbés, C., Hardisson, C. \& Sánchez, J. (1991). Nutritional regulation of differentiation and synthesis of an exocytoplasmic deoxyriboendonuclease in Streptomyces antibioticus. J Gen Microbiol 137, 299-305.

Samuni, A. (1975). A direct spectrophotometric assay and determination of Michaelis constants for the $\beta$-lactamase reaction. Anal Biochem 63, 17-26.

Szab6, I., Penyige, A., Barabás, Gy., Szabó, G. \& Dinya, Z. (1989). Production of a Streptomycin-Park Nucleotide Complex by Streptomyces griseus. Antimicrob Agents Chemother 33, 58-62.

Wu, H. C. (1985). Biogenesis of membrane lipoproteins in bacteria. In Microbiology - 1985, pp. 303-307. Edited by L. Leive. Washington, DC: American Society for Microbiology.

Zhu, Y., Engelbert, S., Joris, B., Ghuysen, J. M., Kobayashi, T. \& Lampen, J. O. (1992). Structure, function and fate of the BlaR signal transducer involved in induction of $\beta$-lactamase in Bacillus licheniformis. J Bacteriol 174, 6171-6178.

Received 5 November 1997; revised 18 March 1998; accepted 2 April 1998. 